\title{
Maternal and fetal nutrition in south India
}

\author{
J R SIBERT, MALATI JADHAV，S G INBARAJ
}

British Medical fournal, 1978, 1, 1517-1518

\section{Summary and conclusions}

The relation between the nutrition of the mother and that of her baby was assessed in a south Indian community where malnutrition is common and women do not smoke. Unselected mothers and their infants of over 37 weeks' gestation were studied in two groups: those who paid for their care (150) and a poorer group who did not (172). There were significant differences between the paying and non-paying groups in maternal triceps skinfold thickness, infant weight, and infant length. Overall there was a significant positive correlation between maternal triceps thickness and infant weight, length, and triceps and subscapular skinfold thickness. The correlation with the infant head circumference was less significant.

These findings are further evidence that the nutrition of the mother has an important effect on the nutrition of her baby and that malnutrition is an important reason why Indian babies are lighter than European ones.

\section{Introduction}

There has been much debate about the effects of maternal nutrition on the baby. Ounsted ${ }^{1}$ thought the effect slight and found no serious malnutrition in the mothers of her growthretarded infants, and Smith ${ }^{2}$ and Antonov ${ }^{3}$ found only small changes in birth weight among infants of starved mothers in Holland and Leningrad during the second world war. More recently, however, Stein ${ }^{4}$ found significantly low maternal albumin concentrations in the small-for-gestational-age infants of underprivileged urban Africans, and Whitelaw ${ }^{5}$ showed that maternal obesity correlated well with the amount of subcutaneous fat in the newborn. Moreover, Kapur et $a l^{6}$ found that maternal and infant weight were positively correlated.

In south India both malnutrition and intrauterine growth retardation are serious problems. Women do not smoke tobacco, but many do heavy manual work. We have therefore studied in a Tamil Nadu population the effect of maternal nutrition, as gauged by triceps skinfold thickness, on infant nutrition, as gauged by standard anthropometric measurements.

\section{Subjects and methods}

Mothers and their babies were studied at two hospitals in Vellore, Tamil Nadu, south India: the Christian Medical College Hospital and the Government Pentland Hospital. All mothers of singleton infants over 37 weeks' gestation born on unselected days were studied from August to October 1977.

Two groups were compared: those who paid for their care $(150$ mothers) and those poorer mothers who did not (172 mothers). The first group were the wives of professional and business men, land-

Christian Medical College, Vellore, Tamil Nadu, South India

J R SIBERT, MD, MRCP, visiting Heinz fellow of the British Paediatric Association from the Department of Child Health, University Hospital of Wales, Cardiff (now consultant paediatrician, Llandough Hospital, Penarth, Nr Cardiff)

MALATI JADHAV, MD, DCH, professor, department of child health

S G INBARAJ, MSC, lecturer, department of biostatistics

owners, and owners of larger shops. In contrast, the non-paying group were the wives of rural and urban labourers, peons, and workers in small factories. The food intake of many of the latter group was inadequate. Their diet was largely vegetarian, with rice, millet, and pulses as the main constituents. As the cultural pattern in south India is for women to eat only after the men and children have finished what they want, these mothers suffered particularly from the financial restraints.

As the information we obtained on gestation was often inaccurate, the gestational age of the infants was assessed by the method of Parkin et al. ${ }^{7}$ All but eight of the infants were over 39 weeks' gestation. There were no apparent differences in gestational ages between the paying and non-paying groups (mean: term +3 days and term +4 days respectively). Although the information we collected on maternal age was also unreliable, there were no apparent differences between the two groups (mean 24.3 and 25.2 years). None of the mothers smoked tobacco.

The mothers and infants were measured within 36 hours of birth by one observer (JRS). Interns posted to the child health department helped with Tamil translation. Maternal left triceps skinfold thickness was measured by a Holtain caliper using the method of Tanner and Whitehouse. ${ }^{8}$ Maternal height was also measured. Birth weight was recorded by midwives on beam scales, crown-to-heel-length measured by Cardiff neonatometer, and occipitofrontal head circumference measured with a paper tape measure. Infant skinfold thickness was measured by a Holtain caliper (reading to $0.1 \mathrm{~mm}$ ) at the left triceps and subscapular sites using the methods of Oakley et al. ${ }^{9}$ With all skinfold measurements the caliper was applied until the reading was stable. The data were analysed with the help of the IBM-370/155-11 computer at the Indian Institute of Technology, Madras.

\section{Results}

In considering the whole group of 322 mothers there was a positive correlation between maternal triceps skinfold thickness and the weight, length, triceps and subscapular skinfold thicknesses $(P<0 \cdot 001)$, and head circumference $(P<0.01)$ of their infants. There was also a significant correlation between maternal height and infant length and weight (table I).

TABLE I-Correlation between maternal characteristics and infant anthropometric data (in 322 cases)

\begin{tabular}{|c|c|c|c|c|}
\hline \multirow{2}{*}{$\begin{array}{c}\text { Infant } \\
\text { characteristic }\end{array}$} & \multicolumn{2}{|c|}{ Maternal triceps thickness } & \multicolumn{2}{|c|}{ Maternal height } \\
\hline & $\begin{array}{l}\text { Correlation } \\
\text { coefficient }\end{array}$ & $\begin{array}{l}\text { Significance } \\
\text { level }(\mathbf{P})\end{array}$ & $\begin{array}{l}\text { Correlation } \\
\text { coefficient }\end{array}$ & $\begin{array}{c}\text { Significance } \\
\text { level }(P)\end{array}$ \\
\hline \multirow{3}{*}{$\begin{array}{l}\text { Weight } \\
\text { Length } \\
\text { Head circumference } \\
\text { Triceps skinfold } \\
\text { thickness } \\
\text { Subscapular skinfold } \\
\text { thickness }\end{array}$} & $\begin{array}{l}0.306 \\
0.188 \\
0.141\end{array}$ & $\begin{array}{l}<0.001 \\
<0.001 \\
<0.01\end{array}$ & $\begin{array}{l}0 \cdot 174 \\
0 \cdot 254 \\
0.013\end{array}$ & $\begin{array}{l}<0.01 \\
<0.001 \\
\text { NS }\end{array}$ \\
\hline & $0 \cdot 235$ & $<0.001$ & -0.017 & NS \\
\hline & 0.262 & $<0.001$ & 0.044 & NS \\
\hline
\end{tabular}

NS $=$ Not significant

TABLE II-Infant anthropometric values according to skinfold thickness of their mothers. Values are means $\pm S D$

\begin{tabular}{|c|c|c|c|c|}
\hline & $\begin{array}{c}\text { Infants with } \\
\text { maternal } \\
\text { triceps } \\
<7 \mathrm{~mm} \\
(\mathbf{n}=76)\end{array}$ & $\begin{array}{c}\text { Infants with } \\
\text { maternal } \\
\text { triceps } \\
>12 \cdot 1 \mathrm{~mm} \\
(\mathrm{n}=80)\end{array}$ & $t$ & $\begin{array}{c}\text { Significance } \\
\text { level }\end{array}$ \\
\hline $\begin{array}{l}\text { Weight (g) } \\
\text { Length (cm) }\end{array}$ & $\begin{array}{c}2650 \cdot 5 \pm 385 \cdot 7 \\
47 \cdot 18 \pm 2 \cdot 27\end{array}$ & $\begin{array}{c}2913 \cdot 2 \pm 464 \cdot 0 \\
47 \cdot 89 \pm 2 \cdot 12\end{array}$ & $\begin{array}{r}12 \cdot 16 \\
2 \cdot 01\end{array}$ & $\begin{array}{l}\mathrm{P}<0.001 \\
\mathrm{P}<0.05\end{array}$ \\
\hline $\begin{array}{l}\text { (cm) } \\
\text { Triceps (mm) } \\
\text { Subscapular (mm) }\end{array}$ & $\begin{array}{r}32.91 \pm 1.44 \\
3.37 \pm 0.68 \\
3.23 \pm 0.56\end{array}$ & $\begin{array}{r}33.49 \pm 1.29 \\
3.75 \pm 0.79 \\
3.68 \pm 0.80\end{array}$ & $\begin{array}{l}2 \cdot 63 \\
3 \cdot 29 \\
4 \cdot 05\end{array}$ & $\begin{array}{l}P<0.01 \\
P<0.01 \\
P<0.001\end{array}$ \\
\hline
\end{tabular}


The infants of mothers with skinfold thicknesses less than $7 \mathrm{~mm}$ (less than 25th percentile for the whole group) had significantly smaller anthropometric measurements than those of mothers with skinfold thicknesses greater than $12.1 \mathrm{~mm}$ (greater than 75 th percentile) (see table II).

There were significant differences between the paying and nonpaying groups in infant weight and length and maternal height and triceps skinfold thickness (see table III). Infants weighing under $2500 \mathrm{~g}$ constituted $24 \%$ of the whole group, $15 \%$ of the paying group, and $30 \%$ of the non-paying group.

TABLE III-Infant anthropometric values in paying and non-paying groups. Values are means $\pm S D$

\begin{tabular}{|c|c|c|c|}
\hline & $\begin{array}{c}\text { Paying } \\
(150 \text { cases })\end{array}$ & $\begin{array}{l}\text { Non-paying } \\
\text { (172 cases) }\end{array}$ & $\begin{array}{c}\text { Significance } \\
\text { level (P) }\end{array}$ \\
\hline $\begin{array}{l}\text { Infant weight }(\mathrm{g}) \\
\text { Infant length }(\mathrm{cm}) \\
\text { Infant head } \\
\text { circumference }(\mathrm{cm}) \\
\text { Infant triceps skinfold } \\
\text { (mm) } \\
\text { Infant subscapular } \\
\text { skinfold (mm) } \\
\text { Maternal height (cm) } \\
\text { Maternal skinfold } \\
\text { thickness }\end{array}$ & $\begin{array}{r}2904 \cdot 0 \pm 431 \cdot 5 \\
47.931 \pm 2 \cdot 16 \\
33 \cdot 38 \pm 1 \cdot 58 \\
3.65 \pm 0.77 \\
3.55 \pm 0 \cdot 82 \\
153 \cdot 1 \pm 6.36 \\
11.64 \pm 5 \cdot 36\end{array}$ & $\begin{array}{r}2697 \cdot 7 \pm 386 \cdot 9 \\
47 \cdot 35 \pm 2 \cdot 19 \\
33 \cdot 14 \pm 1 \cdot 50 \\
3 \cdot 52 \pm 0 \cdot 65 \\
3 \cdot 41 \pm 0 \cdot 59 \\
150 \cdot 0 \pm 5 \cdot 27 \\
8 \cdot 68 \pm 4 \cdot 09\end{array}$ & $\begin{array}{c}<0.001 \\
<0.05 \\
\text { NS } \\
<0.1 \text { (NS) } \\
<0.1 \text { (NS) } \\
<0.001 \\
<0.001\end{array}$ \\
\hline
\end{tabular}

\section{Discussion}

The positive correlation we found between maternal triceps skinfold thickness and infant anthropometric measurements is further evidence that the nutrition of the mother affects the nutrition of her baby. The social class differences in these measurements confirm this point, as many of our mothers were appreciably malnourished. Indeed, the mean maternal triceps skinfold thickness in our non-paying group was only $8.7 \mathrm{~mm}$ compared with the $16 \mathrm{~mm}$ found by Turner and Whitehouse ${ }^{8}$ in British young women. Furthermore, the fetal growth retarding factor of maternal smoking was absent in our mothers.

Perinatal mortality in south India is as high as 68.8 per 1000 rural population and 62.8 per 1000 urban population. ${ }^{10}$ This high rate is due partly to problems of intrauterine growth retardation. Our results emphasise the need to pay attention to maternal nutrition in developing countries. Indeed, at least two studies $^{11} 12$ have shown that dietary supplementation during pregnancy benefits the growth of the infants.

In Britain Trussel ${ }^{13}$ and Smalley and Bissenden ${ }^{14}$ have also emphasised the importance of an adequate diet during preg- $\mathbb{D}$ nancy, particularly among immigrants. Furthermore, Davies et $a l^{15}$ have suggested that the growth-retarding effect of maternal smoking is due to poor food intake during pregnancy. Our work $\stackrel{0}{\rightarrow}$ has added to the evidence that an adequate maternal diet is $\bar{C}$ necessary for adequate fetal growth-a fact that is important for the West as well as developing countries.

We thank the British Paediatric Association and H J Heinz company for funding the fellowship of JRS. We also thank Professor $S \mathrm{X}$ Charles, head of the department of obstetrics and gynaecology, $\vec{O}$ Christian Medical College, and Dr K Kalyaram, district medical officer, North Arcot District, Tamil Nadu, for letting us study $\vec{\omega}$ patients under their care, and Dr D P Davies and Mr R Newcombe for their help.

\section{References}

1 Ounsted, M, Fetal Growth. London, Churchill, 1971.

2 Smith, C A, Fournal of Pediatrics, 1947, 30, 229.

${ }^{3}$ Antonov, A N, Fournal of Pediatrics, 1947, 30, 250

${ }^{4}$ Stein, H, Archives of Disease in Childhood, 1975, 50, 146.

5 Whitelaw, A G C, British Medical fournal, 1976, 1, 985.

${ }^{6}$ Kapur, S, et al, Indian fournal of Medical Research, 1971, 59, 1480

' Parkin, J M, Hey, C N, and Clowes, J S, Archives of Disease in Childhood, $1976,51,252$

${ }^{8}$ Tanner, J M, and Whitehouse, R H, Archives of Disease in Childhood, $\overrightarrow{6}$ $1975,50,142$.

- Oakley, J R, Parsons, R J, and Whitelaw, A G L, Archives of Disease in Childhood, 1977, 52, 287.

${ }^{10}$ Rao, P S S, and Inbaraj, S G, Indian Pediatrics, 1975, 12, 221.

11 Qureshi, S, et al, Indian Pediatrics, 1973, 10, 541.

${ }^{12}$ Lechtig, A, et al, Pediatrics, 1975, 56, 508.

${ }^{13}$ Trussell, R R, fournal of Maternal and Child Health, 1977, 2, 80

${ }^{14}$ Smalley, C, and Bissenden, J, fournal of Maternal and Child Health, $1977,2,408$.

${ }^{15}$ Davies, D P, et al, Lancet, 1976, 1, 385.

\title{
Haemolytic-uraemic syndrome complicating shigella dysentery in south Indian children
}

\author{
P RAGHUPATHY, ANAND DATE, J C M SHASTRY, A SUDARSANAM, MALATI JADHAV
}

British Medical fournal, 1978, 1, 1518-1521

\section{Summary and conclusions}

Shigella dysentery caused $65 \%$ of all cases of acute renal failure (ARF) seen in children treated at the Christian Medical College Hospital, Vellore, during the 33 months ending September 1977. In the 40 children with ARF

\footnotetext{
Christian Medical College and Hospital, Vellore, 632 004, Tami Nadu, India

P RAGHUPATHY, MD, DCH, lecturer, department of child health

ANAND DATE, MD, reader, department of pathology

J C M SHASTRY, MD, DM, head, department of nephrology

A SUDARSANAM, MD, reader, department of clinical pathology

MALATI JADHAV, MD, DCH, professor, department of child health
}

secondary to shigella dysentery, haematological findings suggested that they were suffering from the haemolyticuraemic syndrome, and glomerular hypercellularity 0 and fibrin deposition were present in all 12 patients whose renal histology could be studied. Peritoneal dialysis was the main element of treatment: $43 \%$ of children who underwent dialysis improved, compared with only $25 \%$ of those who did not undergo dialysis.

The haemolytic-uraemic syndrome precipitated by $\stackrel{\mathbb{Q}}{\varnothing}$ bacillary dysentery is therefore the most important $\bar{q}$ cause of ARF in children aged under 5 years in Tamil Nadu and the adjoining area of Andhra Pradesh.

\section{Introduction}

In Tamil Nadu and the adjoining area of Andhra Pradesh shigella dysentery is a common cause of acute renal failure 